\title{
PENINGKATAN HASIL BELAJAR MENULIS CERITA FANTASI DENGAN MENGGUNAKAN METODE PAKEM SISWA KELAS VIII-C SMP NEGERI 5 TENGGARONG TAHUN PELAJARAN 2018/2019
}

\section{IMPROVEMENT OF LEARNING OUTCOME OF WRITING FANTASY STORIES USING PAKEM METHOD ON CLASS VIII-C STUDENTS OF SMP NEGERI 5 TENGGARONG IN 2018/2019 ACADEMIC YEAR}

\author{
Jumairi \\ SMP Negeri 5 Tenggarong \\ Pos-el : jumairi7@yahoo.co.id
}

*) Naskah masuk: 4 Januari 2019. Penyunting: Nur Bety, S.Pd. Suntingan I: 18 April 2019. Suntingan II: 8 Mei 2019

\begin{abstract}
Abstrak
Penelitian ini bertujuan untuk meningkatkan hasil belajar siswa kelas VIII-C SMP Negeri 5 Tenggarong Tahun Pelajaran 2018/2019 dalam menulis cerita fantasi dengan menggunakan metode Pakem. Penelitian ini dilaksanakan dalam tiga siklus. Setiap siklus terdiri atas perencanaan, pelaksanaan, pengamatan, dan refleksi. Berdasarkan hasil olah dapat disimpulkan bahwa penggunaan metode PAKEM dalam pembelajaran menulis cerita fantasi dapat meningkatkan hasil belajar siswa kelas VIII-C SMP Negeri 5 Tenggarong tahun pelajaran 2018/2019.
\end{abstract}

Kata kunci: hasil belajar, cerita fantasi, metode PAKEM

Abstract

This study aims to improve learning outcomes of class VIII-C students of SMP Negeri 5 Tenggarong, academic year of 2018/2019, in writing fantasy stories using the Pakem method. It was conducted in 3 (three) cycles and each of them consisted of planning, action, observation, and reflection. Based on the results, it can be concluded that the use of Pakem method in the learning of writing fantasy stories can improve the learning outcomes of class VIII-C students of SMP Negeri 5 Tenggarong in the academic year of 2018/2019.

Keywords: learning outcomes, fantasy stories, PAKEM Method

\section{PENDAHULUAN}

Pembelajaran bahasa Indonesia dengan pokok bahasan khususnya menulis cerita fantasi yang terjadi di SMP Negeri 5 Tenggarong sering tidak membuahkan hasil yang diharapkan. Masalah ini terjadi karena guru bahasa Indonesia dalam proses pembelajaran sering menggunakan pendekatan yang kurang menarik perhatian siswa. Dengan demikian, siswa mengalami kejenuhan 
ketika dalam proses belajar-mengajar, bahkan cenderung menunjukkan sikap pasif ketika proses belajar-mengajar berlangsung. Selain itu, adanya rasa malas dan tidak tertarik siswa untuk menerima materi pelajaran bahasa Indonesia khususnya dalam menulis cerita fantasi masih sering terjadi, bahkan tingkat kepedulian siswa terhadap pelajaran Bahasa Indonesia dalam menulis cerita fantasi tidak terlihat ketika proses belajar-mengajar berlangsung. Pembelajaran masih terfokus pada guru. Siswa hanya menerima materi yang diberikan oleh guru dan tanpa harus berpikir bagaimana mengembangkan materi pembelajaran menulis cerita fantasi secara mandiri. Berdasarkan análisis hasil evaluasi belajar menunjukkan bahwa dari 26 siswa dalam kelas VIII-C terdiri atas 15 laki-laki dan 11 perempuan dengan rata-rata klasikal 68,86\%. Nilai ini tentunya masih berada di bawah nilai ketuntasan belajar secara individual dengan KKM (75\%). Adapun ketuntasan belajar secara klasikal diperoleh nilai rata-rata 58\% yang berada di bawah nilai kriteria ketuntasan klasikal (85\%).

Berdasarkan masalah tersebut, jika hal itu dibiarkan terus-menerus akan berakibat sangat buruk. Oleh karena itu, perlu adanya suatu upaya baru, jelas, dan terarah. Salah satunya adalah guru dapat menggunakan metode PAKEM dalam pembelajaran menulis cerita fantasi. Dengan demikian diharapkan bahwa dengan menggunakan metode PAKEM dalam pembelajaran menulis cerita fantasi dapat meningkatkan hasil belajar siswa kelas VIII-C SMP Negeri 5 Tenggarong tahun pelajaran 2018/2019.

Dengan upaya tersebut tentunya guru diharapkan dapat melakukan inovasi pembelajaran dengan cara mengubah strategi pembelajaran yang lebih menyenangkan dan memberikan motivasi siswa sehingga pembelajaran bahasa Indonesia dalam menulis cerita fantasi lebih menarik dan me- nyenangkan. Strategi pembelajaran yang memberikan harapan dalam pemecahan masalah tersebut adalah strategi pembelajaran yang memiliki ciri-ciri, yaitu (1) mampu memotivasi kreativitas siswa, (2) melakukan inovatif dan menyenangkan siswa, (3) memperbesar penerimaan terhadap perbedaan individu, (4) meningkatkan kemampuan individu, kebaikan budi, kepekaan, dan toleransi, serta (5) menempatkan penilaian proses dan penilaian hasil belajar sebagai hal yang sama pentingnya dalam pembelajaran.

\section{TEORI}

\section{A. Hasil Belajar}

Belajar adalah modifikasi atau memperkuat tingkah laku melalui pengalaman dan latihan. Belajar juga diartikan suatu proses perubahan tingkah laku individu melalui interaksi dengan lingkungan. Hamalik (2007:52) menyatakan bahwa belajar adalah modifikasi atau memperteguh kelakuan melalui pengalaman (learning is defined as the modification or strengthening of behavior through experiencing). Adapun tujuan dari belajar tentunya ingin mendapatkan hasil yang baik. Hasil belajar bukan suatu penguasaan hasil latihan melainkan pengubahan kelakuan. Hasil belajar tampak sebagai terjadi perubahan tingkah laku pada diri siswa yang dapat diamati dan diukur dalam bentuk perubahan pengetahuan, sikap, dan keterampilan. Perubahan tersebut dapat diartikan terjadinya peningkatan dan pengembangan yang lebih baik dibandingkan dengan sebelumnya, misalnya dari tidak tahu menjadi tahu, sikap kurang sopan menjadi sopan dan sebagainya (Hamalik, 2008).

Dalam pelaksanaan pembelajaran di kelas hasil belajar dapat diketahui setelah proses belajar mengajar selesai dan diakhiri dengan sebuah evaluasi. Evaluasi hasil 
belajar adalah keseluruhan kegiatan pengukuran (pengumpulan data dan informasi), pengolahan, penafsiran, dan pertimbangan untuk membuat keputusan tentang tingkat hasil belajar yang dicapai oleh siswa setelah melakukan kegiatan belajar dalam upaya mencapai tujuan pembelajaran yag telah ditetapkan (Hamalik, 2007:159)

Dalam pelaksanaan pembelajaran tentunya sangat ditentukan oleh prinsip-prinsip belajar yang merupakan bagian dari belajar. Menurut William Burton dalam Hamalik (2004:31) menyimpulkan uraiannya tentang prinsip-prinsip belajar, yaitu (1) proses belajar ialah pengalaman, berbuat, mereaksi, dan melampaui (under going), (2) proses itu melalui bermacam-macam ragam pengalaman dan mata pelajaran-mata pelajaran yang terpusat pada suatu tujuan tertentu, (3) pengalaman belajar secara maksimum bermakna bagi kehidupan murid, (4) pengalaman belajar bersumber dari kebutuhan dan tujuan murid sendiri yang mendorong motivasi yang kontinyu, (5) proses belajar dan hasil belajar disyarati oleh hereditas dan lingkungan, (6) proses belajar dan hasil usaha belajar secara materiil dipengaruhi oleh perbedaan- perbedaan individu di kalangan murid-murid, (7) proses belajar berlangsung secara efektif apabila pengalaman-pengalaman dan hasil-hasil yang diinginkan disesuaikan dengan kematangan murid, dan (8) proses belajar yang terbaik apabila murid mengethui status dan kemajuan.

Keberhasilan dalam kegiatan proses belajar mengajar sangat dipengaruhi oleh faktor belajar. Menurut Hamalik (2004:32 33) faktor-faktor belajar sebagai berikut.

1) Faktor kegiatan, penggunaan dan ulangan; siswa yang melakukan banyak kegiatan baik kegiatan neural system, seperti melihat, mendengar, merasakan, berpikir, kegiatan motorik, dan sebagainya maupun kegiatan-kegiatan lainnya yang diperlukan untuk memperoleh pengetahuan, sikap, kebiasaan, dan minat. Apa yang telah dipelajari perlu digunakan secara praktis dan diadakan penguasaan hasil belajar menjadi lebih mantap.

2) Belajar memerlukan latihan, seperti relearning, recalling, dan reviewing agar pelajaran yang terlupakan dapat dikuasai kembali dan pelajaran yang belum dikuasan akan dapat lebih mudah dipahami.

3) Belajar siswa akan lebih berhasil jika siswa merasa lebih berhasil dan mendapatkan kepuasannya. Belajar hendaknya dilakukan dalam suasana yang menyenangkan.

4) Siswa yang belajar perlu mengetahui apakah ia berhasil atau gagal dalam belajarnya. Keberhasilan akan menimbulkan kepuasan dan mendorong belajar lebih baik sedangkan kegagalan akan menimbulkan frustasi.

5) Faktor asosiasi besar manfaatnya dalam belajar karena semua pengalaman belajar antara yang lama dengan yang baru secara berurutan diasosiasikan, sehingga menjadi suatu kesatuan pengalaman.

6) Pengalaman masa lampau (bahan apersepsi) dan pengertian pengertian yang telah dimiliki oleh siswa besar peranannya dalam proses belajar. Pengalaman dan pengertian itu menjadi dasar untuk menerima pengalaman-pengalaman baru dan pengertian-pengertian baru.

7) Faktor kesiapan belajar. Murid yang telah siap belajar akan dapat melakukan kegiatan belajar lebih mudah dan lebih berhasil. Faktor kesiapan ini erat hubungannya dengan masalah kematangan, minat, kebutuhan, dan tugas-tugas perkembangan.

8) Faktor minat dan usaha. Belajar dengan minat akan mendorong siswa belajar 
lebih baik daripada belajar tanpa minat. Minat ini akan timbul bila murid tertarik akan sesuatu karena sesuatu dengan kebutuhannya atau merasa sesuatu yang akan dipelajari dirasakan bermanfaat bagi dirinya. Namun demikian, minat tanpa adanya usaha yang baik maka belajar juga sulit untuk berhasil.

9) Faktor-faktor fisiologis. Kondisi badan siswa yang belajar sangat berpengaruh dalam proses belajar. Badan yang lemah akan lebih menyebabkan perhatian tak mungkin akan melakukan kegiatan belajar yang sempurna. Karena itu factor fisiologis sangat menentukan berhasil atau tidaknya murid yang belajar.

10) Faktor intelegensi. Murid yang cerdas akan lebih berhasil dalam kegiatan belajar karena ia lebih mudah menangkap dan memahami pelajaran dan lebih mudah mengingat-ingatnya. Anak yang cerdas akan lebih mudah berfikir kreatif dan lebih cepat mengambil keputusan. Hal ini berbeda dengan siswa yang kurang cerdas, dan para siswa yang lamban.

\section{B. Menulis Cerita Fantasi}

1. Menulis

Menurut Hernowo (2002: 116) menulis adalah melahirkan perasaan atau pikiran dengan tulisan. Dengan demikian menulis adalah serangkaian kegiatan untuk mengemukakan pendapat atau ide atau gagasan dalam bentuk lambang bahasa tulis agar dapat dibaca oleh orang lain. Dalam menulis diperlukan adanya kompleksitas kegiatan untuk menyusun karangan secara baik karena melibatkan cara berfikir yang teratur dan berbagai persyaratan yang berkaitan dengan teknik penulisan. Persyaratan tersebut, yaitu (1) adanya kesatuan gagasan, (2) penggunaan kalimat yang jelas, (3) paragraf disusun dengan baik, (4) penerapan kaidah ejaan yang benar, (5) penguasaan kosakata yang memadai. Berdasarkan uraian tersebut di atas dapat didefinisikan menulis adalah serangkaian proses kegiatan yang kompleks yang memerlukan tahapantahapan dan menuangkannya ke dalam bentuk tulisan sehingga pembaca dapat memahami isi dari gagasan yang disampaikan.

\section{Unsur-Unsur Menulis}

Dalam membuat sebuah tulisan, diperlukan beberapa unsur yang harus diperhatikan. Menurut The Liang Gie (1992:17) unsur menulis terdiri atas (1) gagasan/topik yang berupa pendapat, pengalaman, atau pengetahan seseorang. Gagasan tergantung pada pengalaman masa lalu atau pengetahuan seseorang, (2) tuturan merupakan pengugkapan gagasan yang dapat dipahami pembaca. Ada bermacam-macam tuturan, antara lain deskripsi, persuasi, narasi, argumentasi dan eksposisi, (3) tatanan adalah aturan yang harus diindahkan ketika mengungkapkan gagasan. Berarti menulis tidak sekadar menulis, harus mengindahkan aturan-aturan dalam menulis, misalnya penggunaan ejaan yang tepat, dan (4) wahana sering juga disebut dengan alat. Wahana berupa gramatika, kosakata, dan retorika (seni memakai bahasa). Pada penulis pemula, wahana sering menjadi masalah. Mereka menggunakan kosakata, gramatika dan retorika yang masih sederhana dan terbatas. Untuk mengatasi hal tersebut penulis harus memperkaya yang belum diketahui artinya. Seorang penulis harus rajin menulis dan membaca.

\section{Manfaat Menulis}

Menurut Ahmadi (1982) beberapa manfaat menulis, antara lain (1) dengan menulis dapat lebih mengenali potensi yang ada pada diri yang berkaitan dengan permasalahan yang sedang ditulis, (2) melalui menulis dapat mengembangkan berbagai gagasan yang ingin dikemukakan dalam 
tulisan dalam bentuk teks, (3) dari menulis, dapat memperluas wawasan kemampuan dalam berpikir, baik dalam bentuk teoretis maupun dalam berpikir terapan, (4) melalui tulisan dapat menilai gagasan sendiri secara objektif, (5) dengan menulis dapat memotivasi diri untuk belajar dan membaca lebih giat. Penulis menjadi penemu atau pemecah masalah, bukan hanya sekadar menjadi penyadap informasi dari orang lain, dan (6) dengan menulis dapat membiasakan diri untuk berpikir dan berbahasa secara tertib, memperluas, dan meningkatkan pertumbuhan kosakata, meningkatkan kelancaran tulis-menulis dan menyusun kalimat.

\section{Pengertian Fantasi}

Menurut Ahmadi (1982) mendefinisikan fantasi (khayalan, angan-angan, imaginasi) adalah kekuatan jiwa untuk menciptakan tanggapan baru dalam jiwa kita dengan pertolongan tanggapan-tanggapan yang telah dimiliki. Jadi, dengan kekuatan fantasi manusia dapat melepaskan diri dari keadaan yang dihadapinya dan mampu menjangkau ke depan, keadaan yang akan datang.

Menurut Subiyanton, dkk. (1980:18) fantasi adalah kemampuan jiwa untuk membentuk tanggapan-tanggapan atau bayangan-bayangan baru. Dengan fantasi manusia dapat melepaskan diri dari keadaan yang dihadapinya dan menjangkau ke depan, ke keadaan yang akan mendatang. Sementara itu, Simanjuntak (2007:108), fantasi (imajinasi) adalah kemampuan jiwa yang dapat membentuk satu tanggapan baru dengan pertolongan tanggapan yang lama.

\section{Macam-macam Fantasi}

Ada beberapa macam manfaat fantasi bagi kita, antara lain (1) fantasi disadari, yaitu fantasi yang terjadinya disadari oleh individu yang bersangkutan, (2) fantasi yang tidak disadari, yaitu fantasi yang terjadinya tanpa disadari atau disengaja oleh yang bersangkutan, (3) fantasi aktif, yaitu fantasi yang terjadinya melibatkan secara aktif gejala-gejala jiwa lainnya, seperti pikiran, kemauan, perasaan, dan seterusnya, (4) fantasi pasif, yaitu fantasi yang terjadinya tidak melibatkan gejala-gejala jiwa lainnya secara pasif, (5) fantasi mencipta, yaitu fantasi aktif yang mampu menghasilkan karya kreatif, misalnya lagu, lukisan, cerpen, novel, dan (6) fantasi tuntunan, yaitu fantasi aktif yang yang terjadinya di bawah tuntunan sesuatu, misalnya fantasi yang timbul pada saat membaca novel, melihat film, dan mendengarkan lagu.

\section{Kegunaan Fantasi}

Adapun kegunaan fantasi bagi manusia adalah sebagai berikut: (1) Dengan daya fantasinya, manusia mampu membuat karya kreatif, (2) Dengan daya fantasinya, manusia dapat masuk kedunia imajiner, misalnya pada saat membaca novel, dan (3) Dengan fantasi pasif (melamun), manusia dapat menghibur dirinya sejenak (asal tak terus menerus)

\section{Metode PAKEM}

Metode PAKEM adalah pembelajaran aktif, kreatif, efektif, dan menyenangkan. Pengertian PAKEM dapat dilihat dari dua segi, yaitu dari segi guru dan dari segi siswa. Dari segi guru, PAKEM adalah pembelajaran yang aktif, bahwa seorang guru harus memantau kegiatan belajar siswa, memberi umpan balik, mengajukan pertanyaan kepada siswa, memanfaatkan modalitas belajar siswa baik visual, auditorial dan kinestetik dalam pembelajaran. Kreatif, dimaksudkan adalah seorang guru bisa mengembangkan kegiatan yang beragam, membuat alat bantu belajar yang sederhana dan lain- lain. Efektif, yaitu seorang guru dalam proses pembelajaran harus mampu mencapai tujuan pembelajaran yang ingin dicapai. Menyenangkan maksudnya bahwa dalam proses pembelajaran seorang guru diharapkan tidak 
membuat siswa takut salah, takut ditertawakan, takut dianggap sepele dengan diselingi kegiatan bermain atau kegiatan yang lain yang membuat anak merasa senang dalam belajar. Dari segi siswa, PAKEM adalah pembelajaran yang aktif bahwa siswa aktif bertanya, mengemukakan pendapat, merespon gagasan orang lain dalam kegiatan belajar mengajar. Dalam hal ini siswa tidak ingin menjadi penonton, melainkan ikut aktif dalam pembelajaran dengan selalu mencoba hal-hal baru yang menantang sehingga siswa menjadi aktif dan tidak pasif. Kreatif dimaksudkan bahwa siswa bisa merancang atau membuat hasil karya, seperti menulis, mengarang, melukis atau yang lainnya yang membuat anak kreatif.

Dalam hal ini siswa tidak mudah putus asa dan puas dengan hasil kerjanya sehingga siswa ingin mencoba dan membuat inovasi baru. Efektifadalah siswa dibiasakan menggunakan waktu sebaik-baiknya dengan mengajak siswa langsung ke sumber belajar dengan memanfaatkan alat peraga yang ada sehingga pembelajaran menjadi efektif dan sesuai dengan rencana pembelajaran. Menyenangkan, yaitu dalam proses pembelajaran harus membuat anak asyik dan nyaman, dengan mengatur ruang kelas yang menarik, memajang hasil belajar anak di kelas, anak didekatkan ke dunia nyata sehingga anak asyik belajar. Bagi siswa yang berprestasi, guru memberikan penghargaan atas prestasinya. Hal ini membuat anak tertantang

Dalam Kurikulum Tingkat Satuan Pendidikan mengisyaratkan bahwa proses pembelajaran yang ideal adalah pembelajaran yang dapat merangsang peserta didik untuk dapat mengungkapkan segala potensi dirinya untuk dapat meraih sekian kompetensi sesuai dengan bakat dan minatnya, bukan sebaliknya hanya disuapi oleh guru dengan segala macam pengetahuan. Pembelajaran yang bermakna juga demi- kian, mengedepankan pengembangan potensi peserta didik sehingga pembelajaran bukan bersumber atau terfokus pada guru, melainkan terpusat pada peserta didik. Proses pembelajaran yang demikian idealnya dilakukan dengan cara yang santun dan menyenangkan bukan dengan doktrinisasi dan intimidasi/tekanan sehingga dapat dikatakan pembelajaran tersebut adalah pembelajaran ramah anak atau dengan prinsip asah, asih, asuh.

Ada beberapa indikator/tolok ukur bahwa pembelajaran dapat dikategorikan sudah PAKEM sebagai berikut.

(1) Metode Pembelajaran

a. Kegiatan belajar siswa menggunakan metode pembelajaran yang bervariasi (wawancara, pengamatan, bermain peran, penelitian yang berlangsung di luar dan di dalam kelas) sesuai dengan mata pelajaran. Idealnya lebih dari tiga jenis.

b. Kegiatan belajar siswa menggunakan metode pembelajaran yang sesuai dengan spesifikasi bahan ajar.

c. Penggunaan metode dalam kegiatan belajar siswa sesuai dengan RPP.

(2) Pengelolaan Kelas

a. Kegiatan belajar siswa variatif (individual, berpasangan, kelompok, klasikal).

b. Kelompok belajar siswa beragam (gender, sosial-ekonomi, intelegensi).

c. Keanggotaan kelompok belajar berubah-ubah sesuai kebutuhan belajar

(sesuai KD, materi, metode, dan alat bantu belajar).

d. Kegiatan pembelajaran menggunakan tata tempat duduk (meja/kursi) 
yang memudahkan siswa berinteraksi dengan guru maupun dengan siswa lainnya.

e. Tata tertib kelas dibuat dan disepakati bersama antara siswa dan guru.

(3) Keterampilan Bertanya

a. Pertanyaan yang diajukan guru dapat memancing/ mendukung siswa dalam membangun konsep/ gagasannya secara mandiri.

b. Guru mengajukan pertanyaan selalu memberikan jeda (waktu tunggu) yang memberikan keleluasaan seluruh siswa untuk berpikir, lalu menunjuk siswa yang harus menjawab tanpa pilih kasih secara acak.

c. Guru juga mendorong siswa untuk bertanya, berpendapat, dan/atau mempertanyakan gagasan guru/ siswa lain.

d. Siswa menjawab pertanyaan guru dengan lebih dulu mengacungkan tangan tanpa suasana gaduh.

e. Siswa berani bertanya, berpendapat dan/atau mempertanyakan pendapat baik secara lisan/tulisan.

(4) Pelayanan Individual

(a) Terdapat program kegiatan belajar mandiri siswa yang terencana dan dilaksanakan dengan baik.

(b) Siswa dapat menyelesaikan tugas / permasalahannya dengan membaca, bertanya, atau melakukan pengamatan dan percobaan.

(c) Guru melakukan identifikasi, merancang, melaksanakan, mengevaluasi, dan menindaklanjuti program pembelajaran individual (PPI) sebagai respon adanya kebutuhan khusus (hiperaktif, autis, lamban, dsb). (d) Kegiatan pembelajaran melayani perbedaan individual (tipe belajar, siswa: audio, visual, motorik, audiovisual, audio-visual-motorik) menggunakan multimedia. Siswa melakukan kegiatan membaca dan menulis atas keinginan sendiri dan didokumentasikan.

(5) Sumber Belajar dan Alat Bantu Pembelajaran

(a) Guru menggunakan berbagai sumber belajar (sudut baca, perpustakaan, lingkungan sekitar) yang sesuai dengan kompetensi yang dikembangkan.

(b) Guru membuat alat bantu pembelajaran sesuai dengan kompetensi yang dikembangkan sendiri dan / atau bersama siswa/orangtua siswa.

(c) Guru terampil/menguasai alat bantu pembelajaranyang tersedia dan sesuai dengan materi yang diajarkan.

(d) Lembar kerja mendorong siswa dalam menemukan konsep/ gagasan/ rumus/cara (tidak hanya mengerjakan perintah) dan dapat menerapkannya dalam konteks kehidupan nyata sehari-hari.

(e) Umpan balik dan evaluasi, yaitu (1) guru memberikan umpan balik yang menantang (mendorong siswa untuk berpikir lebih lanjut) sesuai dengan kebutuhan siswa, (2) guru memberikan umpan balik (lisan atau tulisan) secara individual. (3) guru menggunakan berbagai jenis penilaian (tes dan nontes) dan memanfaatkannya untuk kegiatan tindak lanjut. (4) setiap proses dan hasil pembelajaran disertai dengan penghargaan dan pengakuan secara verbal atau nonverbal. 
(f) Komunikasi dan interaksi, yaitu (1) bantuan guru kepada siswa dalam pembelajaran bersifat mendorong untuk berpikir, misalnya dengan mengajukan pertanyaan kembali, (2) setiap pembelajaran terbebas dari ancaman dan intimidasi yang ditandai dengan tidak ada rasa takut, labelling, bulliying, anak menikmati, guru ramah, (3) Setiap proses pembelajaran bebas dari perlakuan kekerasan baik emosional, fisik, dan pelecehan seksual, (4) perilaku warga kelas (siswa dan guru) sesuai dengan tata tertib yang dibuat bersama dan etika yang berlaku, (5) siswa mendengarkan dengan baik ketika guru atau siswa lain berbicara, dan (6) komunikasi terjalin dengan baik antara guru-siswa dan siswa-siswa.

(g) Keterlibatan siswa, yaitu (1) siswa aktif dan merasa nyaman bekerja dalam setiap kegiatan pembelajaran, (2) guru selalu memberikan kesempatan kepada siswa untuk tampil di depan kelas untuk menyajikan/mengemukakan/melakukan sesuatu, dan (3) setiap kerja kelompok ada kejelasan peran setiap siswa dan terlaksana secara bergilir.

(h) Refleksi, yaitu (1) setelah pembelajaran, guru meminta siswa menuliskan atau mengungkapkan kesan dan keterpahaman siswa tentang apa yang telah dipelajari, dan (2) guru melaksanakan refleksi/ perenungan tentang kekuatan dan kelemahan pembelajaran yang telah dilaksanakan.

(i) Hasil karya siswa, yaitu (1) berbagai hasil karya siswa dipajang dan ditata rapi dan diganti secara teratur sesuai perkembangan penyampai- an materi pembelajaran, dan (2) hasil karya siswa adalah murni karya atau buatan siswa sendiri.

(j) Hasil belajar, yaitu (1) hasil belajar siswa memenuhi kriteria ketuntasan minimal (KKM), (2) Siswa mengalami peningkatan kompetensi personal atau sosial sesuai dengan potensinya (kerja sama, toleransi, menyelesaikan konflik secara sehat, bertanggung jawab, dan kepemimpinan), dan (3) siswa mengelami peningkatan rasa percaya diri (kemampuan bertanya, menjawab, dan tampil di depan kelas).

\section{METODE}

Jenis penelitian ini adalah penelitian tindakan kelas (PTK). Penelitian ini dilakukan secara sistematis dan reflektif oleh guru sebagai peneliti yang dimulai sejak disusunnya perencanaan sampai dengan penelitian terhadap tindakan yang nyata di dalam kelas, berupa kegiatan belajar mengajar dengan tujuan untuk memperbaiki kondisi pembelajaran yang dilakukan.

Menurut Sukidin, dkk. (2002) menyatakan bahwa penelitian tindakan kelas adalah suatu bentuk penelaahan penelitian yang bersifat reflektif dengan melakukan tindakan-tindakan tertentu agar dapat memperbaiki dan meningkatkan praktik-praktik pembelajaran di kelas secara lebih profesional.

Subjek penelitian adalah Siswa Kelas VIII-C SMP Negeri 5 Tenggarong sebanyak 26 siswa terdiri atas 15 siswa laki-laki dan 11 siswa perempuan. Objek dalam penelitian ini adalah mata pelajaran Bahasa Indonesia pada pokok bahasan menulis cerita fantasi dengan penerapan pembelajaran metode Pakem.

PTK ini dilaksanakan di SMP Negeri 5 Tenggarong, Jalan Gunung Triyu RT V, 
Kelurahan Jahab, Kecamatan Tenggarong, Kabupaten Kutai Kartanegara. Waktu penelitian dilaksanakan selama empat bulan, yaitu pada Agustus s.d. November semester satu (ganjil) tahun pelajaran 2018/2019.

Rancangan pelaksanaan PTK ini dilakukan dalam tiga siklus. Setiap siklus terdiri atas empat tahapan, yaitu perencanaan (planning), tindakan (acting), pengamatan (observing), dan refleksi (reflecting).

Instrumen yang digunakan dalam penelitian ini, yaitu (1) ceklis digunakan untuk memperoleh data tentang penilaian dokumen berupa RPP dan data aktivitas belajar siswa selama proses pembelajaran berlangsung. Peneliti diminta untuk mengisi instrumen ini dengan cara memberikan tanda cek $(\bullet)$ pada jawaban yang telah disediakan, (2) catatan lapangan adalah bentuk instrumen penelitian yang digunakan pada proses pembelajaran berlangsung untuk memperoleh data observasi tentang aktivitas siswa yang mungkin tidak terdapat dalam ceklis, dan (3) soal evaluasi digunakan untuk mengetahui hasil belajar siswa. Bentuk instrumen ini berupa pilihan bentuk uraian.

Teknik analisis data yang dilakukan berupa (1) Teknik Deskriptif Persentase. Data kuantatif yang diperoleh melalui tes kemudian dianalisis dengan teknik deskriptif persentase dengan cara (a) merekap nilai yang diperoleh, (b) menghitung nilai komulatif dari tiap-tiap aspek, (c) menghitung nilai rata-rata, (d) menghitung presentase dalam ketuntasan belajar.

$$
\begin{aligned}
\mathrm{N} & =\frac{\sum \mathrm{N}}{\mathrm{R}} \\
\text { Keterangan }: \mathrm{N} & =\text { Nilai rata-rata } \\
\sum \mathrm{N} & =\text { Jumlah nilai } \\
\mathrm{R} & =\text { perolehan siswa } \\
& =\text { Jumlah siswa }
\end{aligned}
$$

(2) Teknik Deskriptif Kualitatif. Data kualitatif yang diperoleh melalui observasi, wawancara, dan jurnal dianalisis dengan teknik deskriptif kualitatif. Analisis teknik deskriptif kualitatif dengan langkah reduksi data, sajian data, dan simpulan. Setelah mencatat semua data secara objektif selanjutnya data tersebut direduksi.

Berdasarkan deskripsi dan interprestasi data kemudian dianalisis tentang maknamakna yang mendasari upaya peneliti dalam meningkatkan kemampuan menulis cerita fantasi. Hasil analisis tersebut dapat mengungkapkan struktur dasar dalam meningkatkan kemampuan menulis cerita fantasi yang diharapkan. Analisis data tersebut juga dimaksudkan untuk mengetahui tanggapan siswa terhadap kemampuan siswa dalam menulis cerita fantasi.

Adapun indikator kinerja dalam PTK ini adalah (1) minimal nilai rerata ketuntasan belajar siswa secara individu sebesar $75 \%$ dan (2) minimal nilai rerata ketuntasan belajar siswa secara klasikal 85\%.

Keabsahan data yang digunakan dalam penelitin ini bersumber dari data murni yang berasal dari siswa, guru, dan observer atau teman sejawat yang membantu dalam observasi tindakan. Untuk menjamin ketelitian dalam penelitian dilaksanakan kolaborasi, yaitu peneliti dibantu oleh kolaborator yang terdiri atas guru bahasa Indonesia dan kepala sekolah, baik pada saat pengumpulan data (observasi) maupun pada saat pembahasan data (diskusi).

\section{HASIL PENELITIAN}

Berdasarkan hasil olah data dari penelitian tindakan kelas dalam pembelajaran menulis cerita fantasi dengan menggunakan metode PAKEM siswa kelas VIII-C SMP Negeri 5 Tenggarong tahun pelajaran 2018/ 2019 sebagai berikut.

Siklus I menunjukkan bahwa dari 26 siswa teriri atas 15 orang siswa laki-laki dan 
11 orang siswa perempuan dengan jumlah nilai 1965, sedangkan jumlah nilai maksimal 2600. Perolehan nilai ini baru mencapai 75,5 $\%$ dan belum mencapai ketuntasan belajar secara klasikal (85\%). Dari data tersebut siswa yang telah tuntas belajar sebanyak 15 orang $(57,6 \%)$, sedangkan siswa yang belum tuntas dalam belajar sebanyak 11 orang dengan persentase $(42,4 \%)$ orang dengan nilai rata-rata masih berada di bawah nilai KKM (75). Ketuntasan belajar siswa secara klasikal baru mencapai $60 \%$ dari ketuntasan klasikal yang diharapkan dalam penelitian ini $(85 \%)$.

\section{Hasil Belajar Siswa pada Siklus I}

\begin{tabular}{|l|c|}
\hline \multicolumn{1}{|c|}{ Kriteria } & Nilai \\
\hline Jumlah nilai & 1965 \\
\hline Jumlah nilai maksimal & 2600 \\
\hline Siswa yang tuntas & 15 \\
\hline Siswa yang belum tuntas & 11 \\
\hline Ketuntasan klasikal (\%) & $60 \%$ \\
\hline
\end{tabular}

Temuan dalam Pembelajaran Siklus I

\begin{tabular}{|c|c|}
\hline $\begin{array}{l}\text { Temuan dalam } \\
\text { Pembelajaran }\end{array}$ & Tindakan yang Dilakukan \\
\hline $\begin{array}{l}\text { 1) Siswa kurang } \\
\text { memperhatikan ketika } \\
\text { dalam proses } \\
\text { pembelajaran. }\end{array}$ & $\begin{array}{l}\text { 1) Guru memberikan } \\
\text { kepada } \\
\text { memperhatikan ketika } \\
\text { berlangsung. }\end{array}$ \\
\hline $\begin{array}{l}\text { 2) Siswa kurang } \\
\text { bersemangat dalam }\end{array}$ & $\begin{array}{l}\text { 2) Guru mengajak semua siswa agar } \\
\text { lebih bersemangat dalam belajar. }\end{array}$ \\
\hline $\begin{array}{l}\text { belajar. } \\
\text { 3) Siswa tidak memiliki } \\
\text { buku catatan siswa } \\
\text { terhadap pelajaran. }\end{array}$ & $\begin{array}{l}\text { 3) Guru mengingatkan kepada } \\
\text { semua siswa agar mempunyai } \\
\text { buku catatan yang digunakan } \\
\text { dalam belajar. }\end{array}$ \\
\hline $\begin{array}{l}\text { 4) Siswa kurang kreatif } \\
\text { dalam belajar. }\end{array}$ & $\begin{array}{l}\text { 4) Guru mengingatkan kepada } \\
\text { semua siswa agar lebih kreatif } \\
\text { dalam belajar. }\end{array}$ \\
\hline
\end{tabular}

Selanjutnya, pada siklus II dilakukan upaya untuk peningkatan nilai dalam pembelajaran menulis cerita fantasi bagi siswa kelas VIII-C SMP Negeri 5 Tenggarong tahun ajaran 2018/2019 dengan melakukan tindakan (refleksi) dengan melihat hasil observasi sebagai akibat ketidakberhasilan siswa dalam siklus I.

Pada siklus II terjadi perubahan peningkatan nilai hasil belajar. Jika pada siklus I perolehan jumlah nilai sebesar 1965, pada siklus II terjadi peningkatan, yaitu sebesar 2005 dengan jumlah nilai maksimal sebesar 2600. Persentase nilai pada siklus II mencapai $77,1 \%$. Nilai ini jika dibandingkan dengan nilai ketuntasan belajar secara klasikal masih di bawah nilai ketuntaan belajar secara klasikal (85\%). Jumlah siswa yang tuntas belajar sebanyak 20 orang, sedangkan jumlah siswa yang belum tuntas dalam belajar pada siklus II sebanyak 6 orang. Ketuntasan belajar secara klasikal pada siklus II sebesar 76\% dari ketuntasan belajar yang ada (85\%). Dengan melihat hasil ketuntasan belajar pada siklus II sebesar $76 \%$, tentunya belum mencapai suatu ketuntasan belajar secara klasikal yang diharapkan (85\%). Untuk mencapai hasil ketuntasan yang sangat diharapkan tersebut, pada pelaksanaan siklus III perlu adanya perbaikan sebagai refleksi guna meningkatkan hasil belajar dalam menulis ceria fantasi siswa kelas VIII-C SMP Negeri 5 Tenggarong tahun 2018/2019.

\section{Hasil Belajar Siswa pada Siklus II}

\begin{tabular}{|l|c|}
\hline \multicolumn{1}{|c|}{ Kriteria } & Nilai \\
\hline Jumlah nilai & \\
\hline Jumlah nilai maksimal & 2600 \\
\hline Siswa yang tuntas & 20 \\
\hline Siswa yang belum tuntas & 6 \\
\hline Ketuntasan klasikal (\%) & $76 \%$ \\
\hline
\end{tabular}




\section{Temuan dalam Pembelajaran Siklus II}

\begin{tabular}{|c|c|c|}
\hline & $\begin{array}{l}\text { Temuan dalam } \\
\text { Pembelajaran }\end{array}$ & Tindakan yang Dilakukan \\
\hline 1) & $\begin{array}{l}\text { Kurangnya } \\
\text { perhatian siswa } \\
\text { dalam proses } \\
\text { pembelajaran. }\end{array}$ & $\begin{array}{l}\text { 1) Memberikan motivasi } \\
\text { kepada siswa untuk } \\
\text { dapat memperhatikan } \\
\text { pelajaran. }\end{array}$ \\
\hline 2) & $\begin{array}{l}\text { Kurangnya } \\
\text { semangat siswa } \\
\text { dalam belajar. }\end{array}$ & $\begin{array}{l}\text { 2) Mengajak semua siswa } \\
\text { agar lebih bersemangat } \\
\text { belajar. }\end{array}$ \\
\hline 3) & $\begin{array}{l}\text { Kurangnya } \\
\text { kreativitas siswa } \\
\text { dalam belajar. }\end{array}$ & $\begin{array}{l}\text { 3) Mengajak siswa agar } \\
\text { lebih kreatif dalam } \\
\text { belajar. }\end{array}$ \\
\hline
\end{tabular}

Pada siklus III, pelaksanaan penelitian tindakan kelas yang dilakukan tentunya telah memberikan perubahan hasil yang sangat signifikan. Dari jumlah siswa sebanyak 26 orang dengan jumlah nilai sebesar 2229 dengan jumlah nilai maksimal sebesar 2600. Jumlah siswa yang telah tuntas belajar pada siklus III sebanyak 26 orang. Jumlah ini tentunya sangat mengalami perubahan yang sangat drastis sekali. Ketuntasan belajar secara klasikal pada siklus III sebesar $100 \%$.

Hasil Belajar Siswa pada Siklus III

\begin{tabular}{|l|c|}
\hline \multicolumn{1}{|c|}{ Kriteria } & Nilai \\
\hline Jumlah nilai & 2229 \\
\hline Jumlah Nilak Maksimal & 2600 \\
\hline Siswa yang tuntas & 26 \\
\hline Siswa yang belum tuntas & - \\
\hline Ketuntasan klasikal (\%) & $100 \%$ \\
\hline
\end{tabular}

Berikut gambaran hasil evaluasi belajar siswa dalam pembelajaran menulis cerita fantasi secara klasikal pada setiap siklus.

\section{Hasil Evaluasi Belajar Siswa dalam Pembelajaran Menulis Cerita Fantasi Secara Klasikal Setiap Siklus}

\begin{tabular}{|c|l|c|l|}
\hline No. & Kegiatan & Klasikal & Keterangan \\
\hline 1. & Siklus I & $60 \%$ & $\begin{array}{l}\text { Belum } \\
\text { tuntas }\end{array}$ \\
\hline 2. & Siklus II & $76 \%$ & $\begin{array}{l}\text { Belum } \\
\text { tuntas }\end{array}$ \\
\hline 3. & Siklus III & $100 \%$ & Tuntas \\
\hline
\end{tabular}

\section{PENUTUP}

Berdasarkan hasil penelitian yang telah dilakukan dapat disimpulkan bahwa penggunaan metode PAKEM dalam pembelajaran menulis cerita fantasi dapat meningkatkan hasil belajar siswa kelas VIII-C SMP Negeri 5 Tenggarong tahun pelajaran 2018/ 2019. Oleh karena itu, penulis menyarankan kepada (1) Guru bahasa Indonesia dapat menerapkan metode PAKEM sebagai upaya dalam meningkatkan hasil belajar siswa dalam menulis cerita fantasi khususnya dan belajar bahasa Indonesia pada umumnya, (2) kepala sekolah dapat mengupayakan peningkatan profesionalisme guru melalui pelatihan-pelatihan yang berkaitan dengan metode-metode pembelajaran, khususnya metode PAKEM, mengupayakan tersedianya fasilitas yang dapat membantu tercapainya kualitas pembelajaran di sekolah, dan (3) dinas pendidikan diharapkan dapat memfasilitasi agar terselenggaranya pelatihanpelatihan bagi pengembangan profesionalisme guru.

\section{DAFTAR PUSTAKA}

Ahmadi, Abu. 1982. Psikologi Umum. Surabaya: PT Bina Ilmu.

Hamalik, Oemar. 1994. Metode Pendidikan. Bandung: Citra Aditya Bakti

xHamalik. Hamalik, Oemar. 2004. Proses Belajar Mengajar. Jakarta: Bumi Aksara. 
Hamalik, Oemar. 2007. Proses Belajar Mengajar. Bandung: Bumi Aksara

Hamalik, Oemar. 2008. Proses Belajar Mengajar. Jakarta : Bumi Aksara.

Hernowo. 2002. Mengikat Makna. Bandung: Kaifa.

Simanjuntak, Julianto. 2007. Perlengkapan Seorang Konselor: Catatan Kuliah dan Refleksi Pembelajar Konseling. Tangerang: LK3
Subiyanto, Yanto dan Dedi Suryadi. 1980. Tanya Jawab Pengantar Psikologi. Bandung.

Sukidin, dkk. 2002. Manajemen Penelitian Tindakan Kelas. Surabaya: Insan Cendekia.

The Liang Gie. 1992. Pengantar Dunia Karang Mengarang. Yogyakarta: Liberty. 